\title{
Correction to: No laughing matter? The potential of political humor as a means of nonviolent resistance
}

\section{S. Noderer}

Published online: 18 January 2021

(C) Arbeitsgemeinschaft für Friedens- und Konfliktforschung e.V. (AFK) und die Autoren 2021

\section{Correction to:}

\section{$\mathrm{Z}$ Friedens und Konflforsch 2020}

https://doi.org/10.1007/s42597-020-00042-0

Due to an organizational discrepancy, an earlier version was prematurely published and later replaced by the final version to include intended editorial corrections.

The original article has been corrected.

(C) Arbeitsgemeinschaft für Friedens- und Konfliktforschung e. V. (AFK) und die Autoren 2020.

The online version of the original article can be found under https://doi.org/10.1007/s42597-02000042-0.

S. Noderer $(\bowtie)$

Faculty: Social Sciences, Institute of Political Science, Universität Duisburg-Essen, Duisburg, Germany

E-Mail: sonja.noderer@stud.uni-due.de 